\title{
Environmental and occupational respiratory diseases - 1055. CD23, TH1/TH2 cytokines in children with bronchial asthma, bronchiolitis and bronchial pneumonia
}

\author{
Anchoju Vijayendra Chary \\ From 2nd WAO International Scientific Conference (WISC 2012) \\ Hyderabad, India. 6-9 December 2012
}

\section{Background}

CD23 (FceRII), is the low-affinity receptor for IgE and considered as a multifunctional cytokine. Soluble CD23 (sCD23) plays an important role in IgE synthesis. The aim of this study was to determine sCD23 and Th1, Th2 cytokines levels in Children with asthma, bronchiolitis and bronchial pneumonia.

\section{Methods}

CD23, Histamine release, total IgE and various Th1, Th2 cytokines were determined in blood samples of patients with bronchial asthma $(n=23)$, bronchiolitis $(n=20)$ and bronchial pneumonia $(n=20)$ and age \& sex matched normal children $(n=20)$ were taken as controls.

\section{Results}

Serum $\mathrm{sCD} 23$ was significantly increased $(\mathrm{p}<0.01)$ in bronchial asthma $(1209.8 \pm 68.01 \mathrm{pg} / \mathrm{mL})$, bronchiolitis $(1455.52 \pm 146.92 \mathrm{pg} / \mathrm{mL})$ and bronchial pneumonia $(1406.35 \pm 98.26 \mathrm{pg} / \mathrm{mL})$ when compared to controls $(691.5 \pm 74.94 \mathrm{pg} / \mathrm{mL})$. Serum IgE and blood histamine levels were increased significantly $(\mathrm{P}<0.05)$ and IFN- $\gamma$ (Th1 cytokine) was significantly lower $(\mathrm{P}<0.01)$ in both bronchial asthma and bronchiolitis than in controls where as IFN- $\gamma$ (Th1 cytokine) increased significantly in bronchial pneumonia compared to the other three groups.

\section{Conclusions}

Our observations provide evidence on CD23 expression in children with and without asthma and a preferential

Microbiology and Immunology, National Institute of Nutrition (ICMR), Hyderabad, India activation of Th2 (IL-5) and suppression of Th1 (IFN- $\gamma$ ) cytokine in children with asthma. Comparable CD23 response in children with bronchial pneumonia and bronchial asthma, suggests nonspecific nature of CD23.

Published: 23 April 2013

doi:10.1186/1939-4551-6-S1-P53

Cite this article as: Chary: Environmental and occupational respiratory diseases - 1055. CD23, TH1/TH2 cytokines in children with bronchial asthma, bronchiolitis and bronchial pneumonia. World Allergy Organization Journal 2013 6(Suppl 1):P53.
Submit your next manuscript to BioMed Central and take full advantage of:

- Convenient online submission

- Thorough peer review

- No space constraints or color figure charges

- Immediate publication on acceptance

- Inclusion in PubMed, CAS, Scopus and Google Scholar

- Research which is freely available for redistribution

Submit your manuscript at www.biomedcentral.com/submit
() Biomed Central 